\title{
A NEW APPROACH OF LEARNERS' ASSESSMENT USING BLOOM'S TAXONOMY-BASED SERIOUS GAME
}

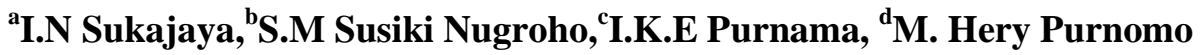 \\ ${ }^{a}$ Department of Electrical Engineering, Institut Teknologi Sepuluh Nopember, Surabaya \\ ${ }^{\mathrm{b}, \mathrm{c}, \mathrm{d}}$ Department of Multimedia \& Network Engineering, Institut Teknologi Sepuluh \\ Nopember, Surabaya \\ ${ }^{a}$ Department of Educational Mathematics, Universitas Pendidikan Ganesha, Singaraja-Bali \\ E-Mail: nyoman.sukajaya@undiksha.ac.id
}

\begin{abstract}
Abstrak
Naskah ini mendeskripsikan skenario, spesifikasi agen, peta pengetahuan, implementasi serious game berbasis taksonomi Bloom (BoTySeGa), serta tanggapan pengguna terhadap game yang dibangun. Pembangunan BoTySeGa bertujuan menyediakan alternatif alat penilaian yang dibutuhkan dalam penilaian pembelajaran di SD. Pembangunan mempertimbangkan aspek: pengetahuan permainan, materi bangun datar jajaran genjang siswa SD kelas 5, dan domain kognitif menurut Bloom. Level tantangan disusun mengikuti aspek domain kognitif Bloom yang diaplikasikan di jenjang SD (pengetahuan, pemahaman dan aplikasi). Game yang dihasilkan diuji melalui uji penerimaan pengguna (UAT) untuk meyakini semua fungsi dan fitur berfungsi dengan benar. Uji juga mencakup tanggapan pengguna yang dilakukan menggunakan kuesioner skala Likert dengan lima pilihan dan lima belas item pertanyaan. Uji dengan melibatkan 85 pengguna diperoleh hasil bahwa BoTySeGa memenuhi spesifikasi kebutuhan penilaian pembelajaran. Dengan rentangan skor tanggapan 5 - 75; rata-rata skor tanggapan dari pengguna sebesar 59,93 dan berada dalam kategori tanggapan "Positif".
\end{abstract}

Kata kunci: Penilaian Pembelajaran, Taksonomi Bloom, Permainan Serious.

\section{Abstract}

This paper describes: a scenario, agent specification, mapping of knowledge domain, an implementation of Bloom's taxonomy-based serious game (BoTySeGa), and players' response against the game. The development of BoTySeGa is pursued to the availability of an alternative assessment tool for learning in elementary school. It considers aspects: game knowledge, subject matter of parallelogram for $5^{\text {th }}$ grade elementary school learners, and cognitive domain of Bloom's taxonomy. BoTySeGa's level of challenge is structured accommodates cognitive domain of Bloom for elementary school learners (knowledge, comprehension, application). To make sure that all functions and features work well; we conducted user acceptance test against the game prototype. We also took players' response to BoTySeGa utilizing five-points Likert-type of questionnaire. The questions are distributed in 15 items. User acceptance testing involving 85 learners of $5^{\text {th }}$ grade elementary school shows that BoTySeGa has fulfilled the learning assessment requirement. With the response score ranged from 5 to 75; it is found that the average score of players' response to the implementation of BoTySeGa in learning is 59.93. This response value falls within "Positive" category.

Keywords: Learning Assessment, Bloom's Taxonomy, Serious Game. 


\section{INTRODUCTION}

A good assessment is an important part of learning, since it guides students' learning. Misleading assessment potentially leads to incorrect learning approaches conducted by students [1][2][3]. For a long time; assessment has been approached as psychometric issue and purposed for measuring learners' achievement of certain curricular goals. The assessment is mainly focused on validity and reliability as its main criteria. This perspective is referred to as assessment of learning. For learning in the 21th century; we need the implementation of assessment for learning (AfL). Assessment Research Group (ARG) defines AfL which is known as formative assessment as the process of seeking and interpreting evidence for use by learners and their teachers to make decision of learners position in learning, approaches which are conducted by students as the best way to reach the competence. In this perspective; assessment is approached as an educational design issue [4]. Assessment is implemented as a subsequent of learning environments and is required for assuring the existence of constructive alignment between learning, instructional approaches and assessment. When it is properly implemented; research results show that AfL gives beneficial effect on learning [5]. AfL is being tought as a promising pedagogical approach for enhancing students learning [6] due to enquiry process involving the active search for evidence of capability and understanding, making sense of such evidence, and exercising judgment for wise decision making about next steps for students and teachers [7].

Confidence to practice a highly effective pedagogical approach in learning is realized in North America, Western Europe, Australia, and Asia [6] [7]. In contrast with previous research results; AfL practice in learning has identified some problems. The problems involve time and class sizes, teacher misconceptions of AfL philosophy, theory and practice, and perceived misalignment between system accountability priorities and teachers' assessment practices [6] [7] [8] [9] [10]. In case of a big class size and limited time of assessment there is a tendency that less data are available for creating decision. This condition implies that a more subjective assessment is needed for creating a decision [3].

It is defined that assessments with technologies aid are those that integrate authentic experiences, involving digital media, with incorporation of performance measurement, learning and knowledge. It creates a detailed record which is analyzable. Teachers and students use its results to improve learning [11]. Game and game technology are assessments with technology aid which is poised to educate and train students at all levels. One such game among others believed as developing technology is a serious game [3]. Serious Games (SGs) have the potential to offer both an effective and motivating educational experience [12]. Serious game is different from entertainment game due to the existence of assessment component [13] [14] which is really required in learning [13]. It provides an opportunity for players to transferring technology and recording player behavior while playing the game [14]. The history of the application of game technologies in education can be tracked at [15] [16] [17] [18] [19] [20] [21] [22]. But, instructors do not fully embrace serious game in learning. What is it being thought as missing in serious game is the availability of pedagogical and assessment engines [3]. Since the serious game provides learners to practice and apply skills needed in the real world than we need to promote the use of serious game in learning.

Utilization of Bloom's taxonomy in the development of online assessment questions was done by [23]. The domain is based on the hierarchy of thought processes. Each of it requires a more complex thinking than the one preceding it. Thus, in developing item of assessment, we keep in mind that students think, make connections, question the information included in the problem, process the information, and reflect on their answers [23]. It was found that the use of Bloom's taxonomy in learning curriculum framework could increase achievement of learners [24]. Learning should move from the simple to the complex, from the known to the unknown. Each unit should provide a foundation for the units that follow, with increasing complexity and performance milestones that define progress toward the goal of the fully qualified practitioner [25]. Well designed multiple choice questions incorporating different learning domains of Bloom 's taxonomy may be a potential method of assessing critical thinking skills in large classes of students [26].

Due to there is no previous research that applies Bloom's taxonomy into serious game; we 
propose the development of Bloom's taxonomy-based serious game (BoTySeGa). The game integrates a Bloom's taxonomybased assessment framework into game technology. We also adjust level of difficulty challenges considering the player experience in the previous challenge. Three levels of difficulty problems are defined as: low, middle and high. The limitation on the number of level is to deal with the creation complexity of game's problems.

Complexity of thinking of players which is required in solving challenges of BoTySeGa is structured from the simplest to the most complex. The Bloom's taxonomy-based assessment framework is combined with adjustment level of difficulty problems; if it is integrated in serious game is potentially avoids players' early frustration or boredom in playing the game and improve learning outcome [27]. Gameplay data which are recorded using assessment framework are more detailed. It creates less subjective element to be in decision making and approach which will be conducted in learning.

The following sections discuss: literature review, research methodology of the development of BoTySeGa, results, and concluding remark.

\section{LITERATURE REVIEW}

\section{Bloom's Taxonomy}

Bloom's taxonomy is a hierarchy of learning objectives which was published originally by Benjamin Bloom in 1956. The taxonomy involves three aspects of learning domain such as: affective, cognitive, and psychomotoric. Emphasis is given to the second of those three domains of Bloom's taxonomy. At the domain; Bloom categorizes six levels of educational objectives. Those levels are: knowledge (C1), comprehension (C2), application (C3), analysis (C4), synthesis (C5) and evaluation (C6). The first three levels are classified as lower order thinking skills and the others as higher order thinking skills. Each level measures different level of thinking skill complexity. Summary of Bloom's taxonomy is depicted at Figure 1.

In 2000; Anderson and Krathwohl revised Bloom's taxonomy. No addition or reduction in the number of learning objective appears in the revised of Bloom's taxonomy. It is different from the original one as the replacement of

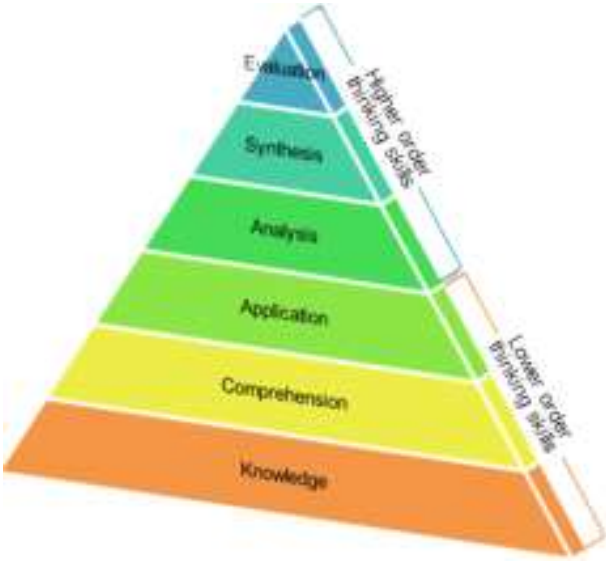

Figure 1. Bloom's Taxonomy Objectives of Cognitive Domain [28]

nouns with verbs for the naming of level. One principle change in the revised Bloom's taxonomy is the switchover the fifth and the sixth level followed by replacement of a word synthesis with create. The six level of the cognitive domain of revised Bloom's taxonomy involves: remember, understand, apply, analyze, evaluate and create. Summary of this revised taxonomy is depicted at Figure 2 and more detailed information of each level is described in Table 1.

Bloom states mastery in a category as the capability to demonstrate skills or abilities defined as objectives in the category. Those skills or abilities are listed from a simpler to more complex of thinking skills.

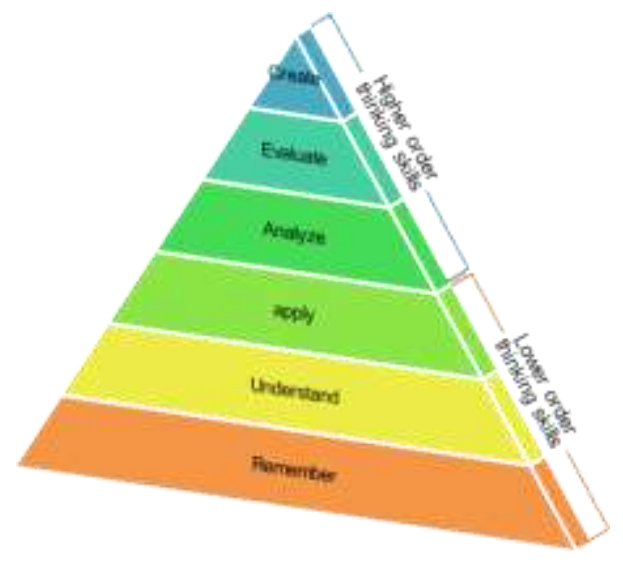

Figure 2. Revised Bloom's Taxonomy Objectives of Cognitive Domain [28] 
It implies the necessary appearance of simpler skills for mastery in more complex skills [29] .

\section{Serious Game and Constructivism Theory}

Early in its evolution; the "serious game" oxymoron pinned to games which are used for education, training, health or public services could be found in a Swedish novel "Den allvarsamma leken" whose English title is "The Serious Game". The novel was written in 1912. Other similar idea could also be found in [30]. The "serious game" oxymoron with a meaning closest to its current meaning used firstly in a book written by [31] entitled "Serious Game". From then on, many creations are found in conjunction with "serious game" oxymoron. They all follows the lead set by white paper Ben Sawyer entitled "Serious Games: Improving Public Policy through Game-based Learning and Simulation" [32]. Other definition of "Serious Games" found in [33], [34], [35], [15]. They commonly deal with the idea that serious games are different from other game due to its ability to transfer knowledge.

Market of serious game technology has been rapidly growing during the twenty first century. A number of 1265 games were produced at an eight year time interval (2002-2010) [36]. What is thought to make serious games rapid growth recently is its potential to assist the implementation of constructivism paradigm in learning [37]. In constructivism paradigm; learners themselves construct knowledge in the way suitable for them as the attempt that they make sense of their experience. It also changes learners' mental model from passive to active process information. Constructivism paradigm is suitable with Piaget [38] and Vygotsky theory [39]. Piaget theory states that learning is held through active exploration and occurred when there is mismatch between theory and experience. Meanwhile; Vygotsky states that learning occurred in social context and the interaction between learners and their peers is necessary part of learning process.

To guarantee serious games assist in the implementation of constructivism paradigm during the learning process; its design should involves the following techniques: modeling, reflection, strategy formation, scaffolded exploration, debriefing, and articulation as depicted at Figure 3 [37]. In the first; people commonly learn through modeling technique. It is a form of demonstration (in the form of simulation or video) followed by impersonation.

Table 1. Summary of objectives of Revised Bloom's Taxonomy [27]

\begin{tabular}{|c|c|c|}
\hline Objectives & Definition & Verbs \\
\hline Create & $\begin{array}{l}\text { Retrieve knowledge from long } \\
\text { term memory }\end{array}$ & $\begin{array}{l}\text { Assemble, construct, create, design, develop, } \\
\text { formulate, write }\end{array}$ \\
\hline Evaluate & $\begin{array}{l}\text { Construct meaning from } \\
\text { instructional messages, including } \\
\text { oral, written, and graphic } \\
\text { communication }\end{array}$ & $\begin{array}{l}\text { Appraise, argue, defend, judge, select, support, } \\
\text { value, evaluate }\end{array}$ \\
\hline Analyze & $\begin{array}{l}\text { Applying a procedure to a } \\
\text { familiar task }\end{array}$ & $\begin{array}{l}\text { Appraise, compare, contrast, criticize, } \\
\text { differentiate, discriminate, distinguish, examine, } \\
\text { experiment, question, test }\end{array}$ \\
\hline Apply & $\begin{array}{l}\text { Break material into its } \\
\text { constituent parts and determine } \\
\text { how the parts relate to one } \\
\text { another and to an overall } \\
\text { structure or purpose }\end{array}$ & $\begin{array}{l}\text { Choose, demonstrate, dramatize, employ, } \\
\text { illustrate, interpret, operate, schedule, sketch, } \\
\text { solve, use, write }\end{array}$ \\
\hline Understand & $\begin{array}{l}\text { Make judgments based on } \\
\text { criteria and standards }\end{array}$ & $\begin{array}{l}\text { Classify, describe, discuss, explain, identify, } \\
\text { locate, recognize, report, select, translate, } \\
\text { paraphrase }\end{array}$ \\
\hline Remember & $\begin{array}{l}\text { Put elements together to form a } \\
\text { coherent or functional whole; } \\
\text { reorganize elements into a new } \\
\text { pattern or structure }\end{array}$ & $\begin{array}{l}\text { Define, duplicate, list, memorize, recall, repeat, } \\
\text { state }\end{array}$ \\
\hline
\end{tabular}




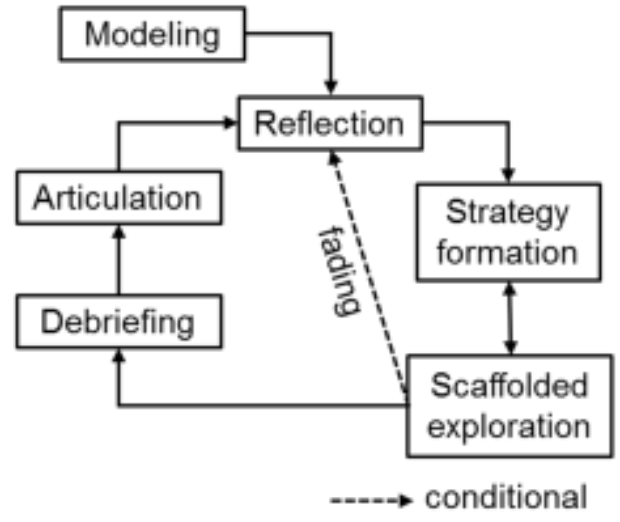

Figure 3. Constructivist Serious Game Framework [37]

Learners observe and construct a conceptual model of the process required to achieve learning objectives. This technique is frequently used in assisting the creation of learners' progress through Zero Proximal Development (ZPD) process (Figure 4).

Reflection compares learners' experience in problem solving with an expert, their peers or ultimate goals. It implies the assurance for the existence of observer who records learners' experience in playing games. Outcome of reflection technique is a decision making whether a new strategy formation is required in game playing. Strategy formation is attributed with changing in intelligence reorganization adjusted for new ideas. Learners should be smart in reorganizing their intelligence to produce accurate strategic playing in problem solving. Scaffolding exploration directs learners to a modus of problem solving suitable for themselves.

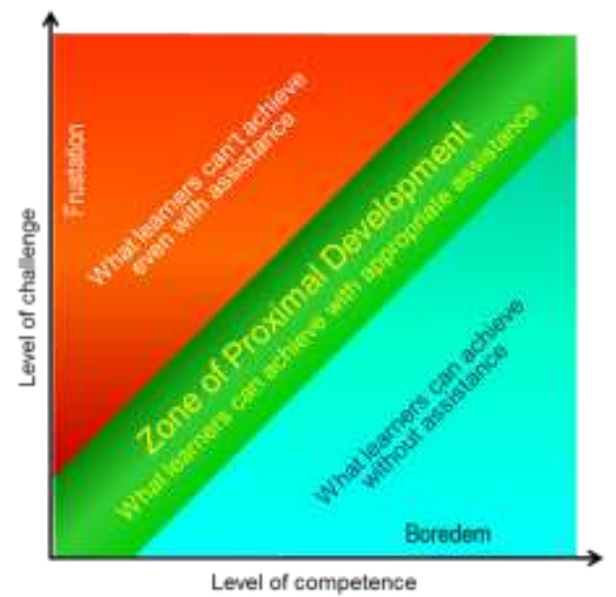

Figutr. 4. Zone of Proximal Development [40]
Scaffolding is aimed at building the learners ability in problem solving independently. The assistance of instructors is gradually reduced in the scaffolding exploration. Players should remember that each action involves risk and there is a requirement to inform how they should play and monitor their progress continuously. In case of a player has achieved the learning objective; instructor's support could be reduced (faded). Many consider debriefing to be the most critical part of the simulation experience. Without this debriefing time, the effectiveness of the activity may be greatly diminished, as some learners will see the activity as a standalone event and not properly connect it to other aspects of the class. If presented appropriately, debriefing helps the students deconstruct the activity and then connect it into their mental models. With Articulation is defined as a players' forum to share experience among them.

\section{RESEARCH METHODOLOGY}

Our research methodology involves the following steps: designing game's scenario of BoTySeGa, designing BoTySeGa's game engine, defining states and procedures conducted in each engine, mapping knowledge content into BoTySeGa's challenges, composing challenges' database, and implementing the game development package (Figure 5). The tool applied for the development is RPG XP game development package.

We conducted user acceptance testing (UAT) before requesting feedback from players to guarantee that the game is fulfilling the requirement. Eighty five Players' responses to BoTySega were gathered utilizing a Likert-type questionnaire. The players are learners of $5^{\text {th }}$ grade of two elementary schools in Singaraja i.e. SD N 3 Banjar Jawa and SD Laboratorium Undiksha. Questions are stressing on psychological aspects of players while playing BoTySeGa. The questions are distributed in 15 items of five points. Those points are: strongly agree (SS), agree (S), undecided (R), disagree (TS), and strongly disagree (STS). Players' responses are quantified by assigning score 1 to 5 to the corresponding unit. 


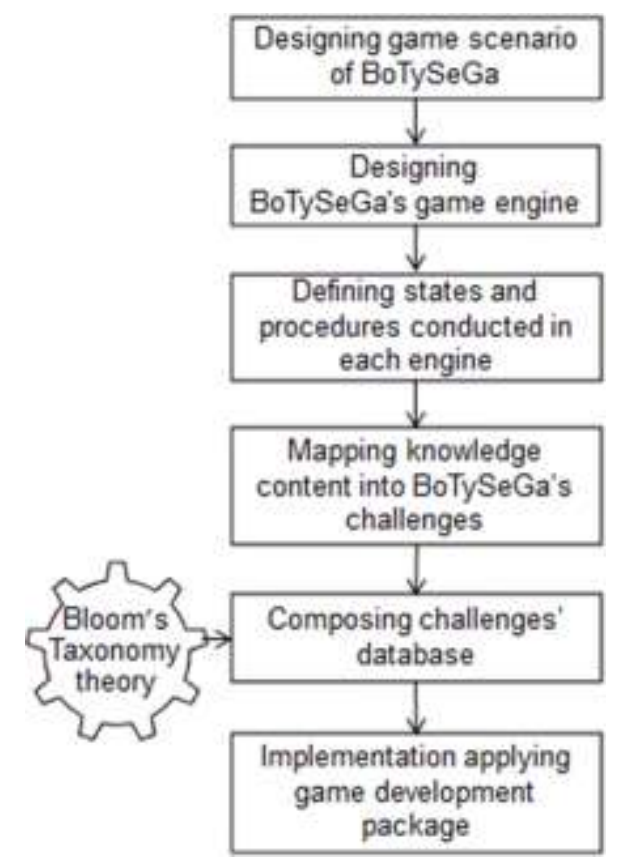

Figure 5. Zone of Proximal Development

Finally; average score $(\mu)$ of 85 respondents are matched to categorization interval which is composed involving the value of ideal mean $\left(m_{i}\right)$ and standard deviation $\left(s d_{i}\right)$ as follows.

$$
\begin{aligned}
& m_{i}=\frac{1}{2}(l i+h i) \\
& s d_{i}=\frac{1}{6}(h i-l i)
\end{aligned}
$$

$l i$ is the lowest and $h i$ is the highest score. The category interval on those both values are:

$$
\begin{array}{rc}
m_{i}+1.5 s d_{i} \leq \mu & \begin{array}{c}
\text { Highly } \\
\text { positive }
\end{array} \\
m_{i}+0.5 s d_{i} \leq \mu<m_{i}+1.5 s d_{i} & \text { Positive } \\
m_{i}-0.5 s d_{i} \leq \mu<m_{i}+0.5 s d_{i} & \text { Average } \\
m_{i}-1.5 s d_{i} \leq \mu<m_{i}-0.5 s d_{i} & \text { Negative } \\
\mu<m_{i}-1.5 s d_{i} & \text { Highly } \\
\text { negative }
\end{array}
$$

\section{Game's Scenario of BoTySeGa}

Game scenario of BoTySeGa is composed as follows. Players are about to be ready to play

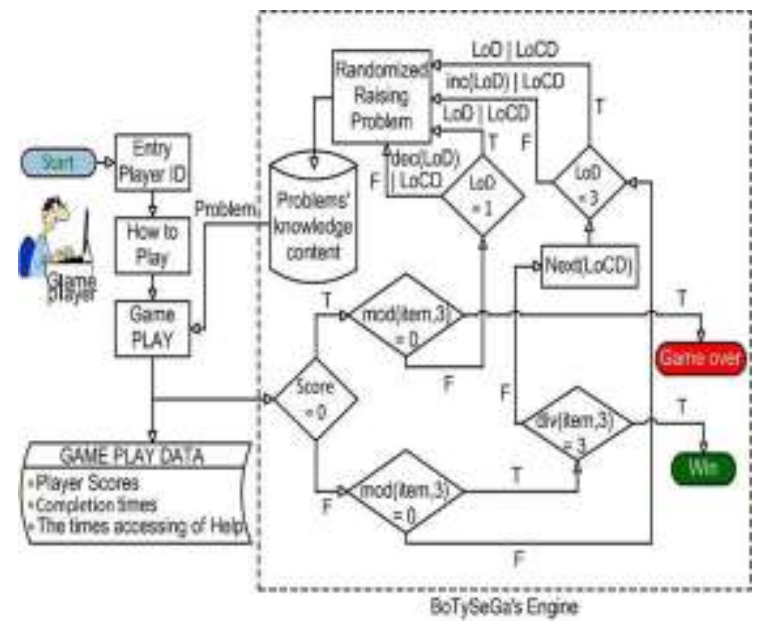

Figure 6. The Design of BoTySeGa Engine

the game after typing their identifier at login process and learned how to play the game. They are allowed to navigate student agent movement to the left, right, bottom, up, or following the instruction that is displayed at pop-up dialog. In Addition, they are also challenged to solve nine problems. The nine problems are distributed into three different stages of the game. Those, who solve problems correctly, are the winners.

The first problem on BoTySeGa is the problem with the middle level of difficulty of $\mathrm{C} 1$ cognitive domain. Players who passed in the first problem will be challenged with the second problem of the similar cognitive domain but with higher level of difficulty. Otherwise, players will be challenged with the similar cognitive domain and the lower level of difficulty. The game generates three problems in each of the cognitive domain. Filtering is conducted in the third problem; in which a correct solution will bring players to continue to the next cognitive domain, otherwise stop up in the current domain. Probability of correctness, state, and description of each players' solution in each problem of a cognitive domain is shown in Table 2. Those players who are passed in $\mathrm{C} 3$ cognitive domain are stated as the winners.

Players are also permitted to access Help before submitting problem solution. Players' experience are recorded as game play data applying database application system. 
Table 2. The Mechanism of Cognitive Domain Changes

\begin{tabular}{|c|c|c|c|c|c|}
\hline \multirow{2}{*}{ No } & \multicolumn{3}{|c|}{ Probability } & \multirow{2}{*}{ State } & \multirow{2}{*}{ Description } \\
\hline & first & second & Third & & \\
\hline 1 & 0 & 0 & 0 & Fail & Totally fail \\
\hline 2 & 0 & 0 & 1 & Pass & There is learning process although it takes long time \\
\hline 3 & 0 & 1 & 0 & Fail & $\begin{array}{l}\text { It is not significant that there is learning process at learner's } \\
\text { individual }\end{array}$ \\
\hline 4 & 0 & 1 & 1 & Pass & There is enough learning process at learner's individual \\
\hline 5 & 1 & 0 & 0 & Fail & Exactly there is no learning process \\
\hline 6 & 1 & 0 & 1 & Pass & There is learning process although there is still doubt \\
\hline 7 & 1 & 1 & 0 & Fail & Gradually shown that there is learning process \\
\hline 8 & 1 & 1 & 1 & Pass & $\begin{array}{l}\text { Learner with excellent start and keep in excellent condition } \\
\text { until end }\end{array}$ \\
\hline
\end{tabular}

\section{BoTySeGa's Game Engine Design}

Design of BoTySeGa's game engine is depicted at Figure 6. In general, we developed two agents inside BoTySeGa game engine, those are: BoTySeGa and student agents.

BoTySeGa's agent equiped with four functions such as: problem selection, seting LoD, filtering players who may proceed to the next level of cognitive domain, and recording player experience. Meanwhile; student agent consist of functions for: login access, access to the Help, and submit a solution.

Furthermore, BoTySeGa is equiped with problems and gameplay database. Challenges' database is created to storage 45 items of challenges. Those items are of three level of cognitive domain and three level of difficulty problem. Gameplay database records players experience while playing the game.

\section{State Design and Procedure of BoTySeGa's Game Engine}

It has been described in the previous section that BotySega's game engine involves two agents. Each of them is equipped with functions. Functions, states of functions, and procedure which is designed in each agent are described below.

\section{The BoTySeGa Agent}

The first function in BoTySeGa agent is a function to select a problem among problems saved in problems database. Input parameters of problems selection's agent are level of difficulty problem (LoD) and cognitive domain (LoCD). Agent selects one among five problems associated with input parameters. Procedure attached at problem selection agent is defined at the following algorithm.

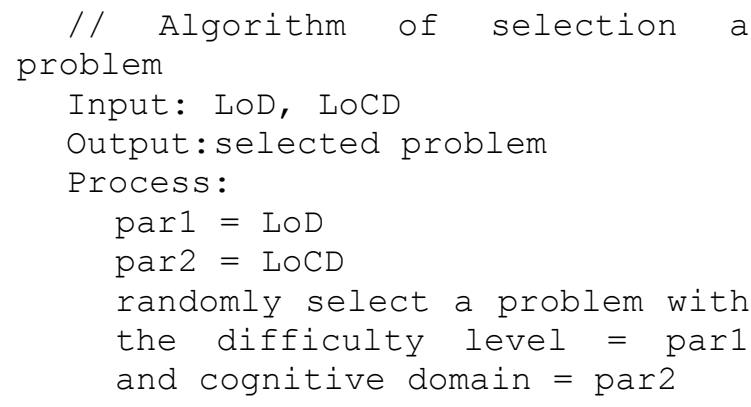

We group the level of difficulty problem in BoTySeGa into three groups. Those are: low, middle, and high. Except for the first problem, the determination of level is based on player experience at the previous problem. Typically, players who are passed at the previous problem will be challenged to solve a problem of a higher level of difficulty. Otherwise they will be challenged to solve a problem of a lower level. In case they are passed to solve a problem with the highest level of difficulty or failed with the lowest level, they will be faced with a problem of the similar level of difficulty. The function output is used as an input parameter of problem selection function. The procedure of determining a level of difficulty problem is shown at the algorithm below.

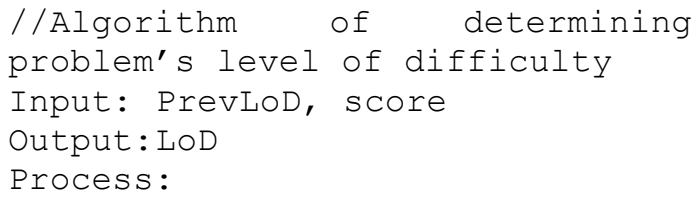




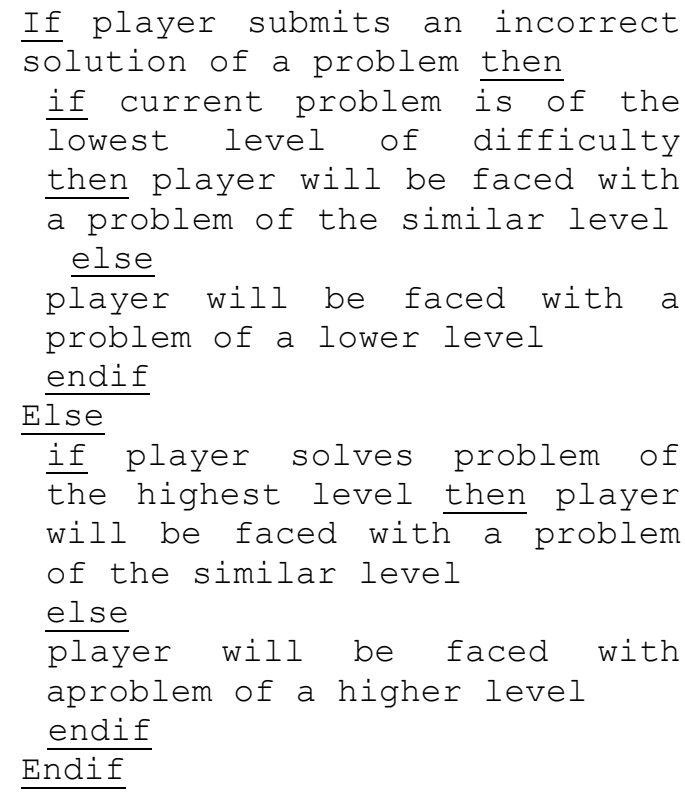

Bloom's taxonomy states that learners' mastery at a cognitive domain affects their mastery on the next domain. BoTySeGa accommodates this state by the way of permitting only players who are passed from a cognitive domain proceeded to the next level. Filtration process whether a player is permitted proceeds or stop in a certain level of cognitive domain refers to the condition which is shown in Table 2. Filtration algorithm is shown as follow.

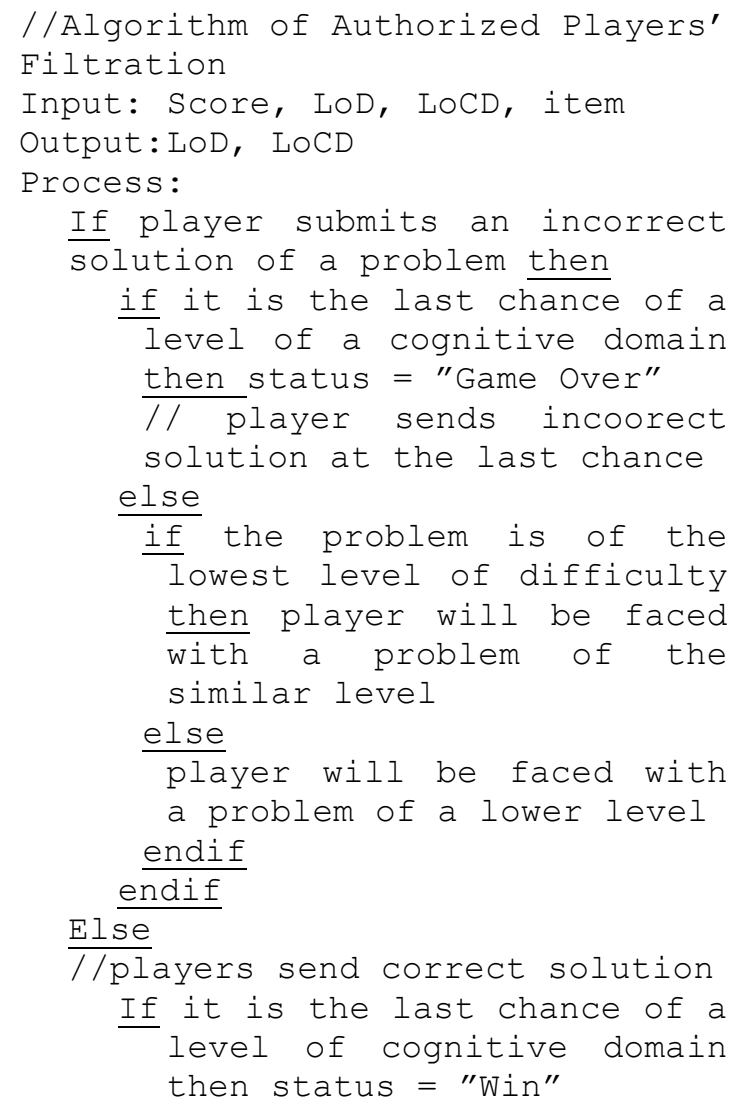

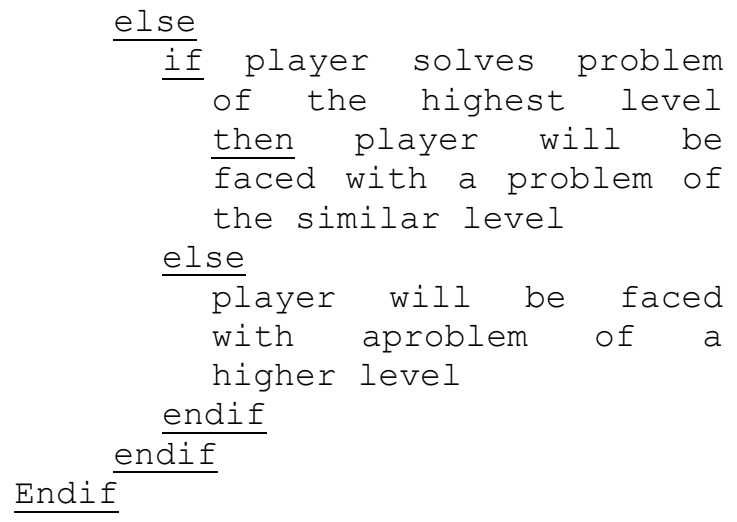

Players' experience within each problem of BoTySeGa is logged into external database and saved as a game play data. Primarily; BoTySeGa logs the values of three attributes of game play data. Those are: score, completion time, and the time of accessing Help. Score is recorded in ordinal data type ranging from 0 to 3 . Meanwhile completion time and the time of accessing Help are recorded in ratio data type. The recording algorithm of players' experience is the last function of BoTySeGa's agent. It is shown in the following algorithm

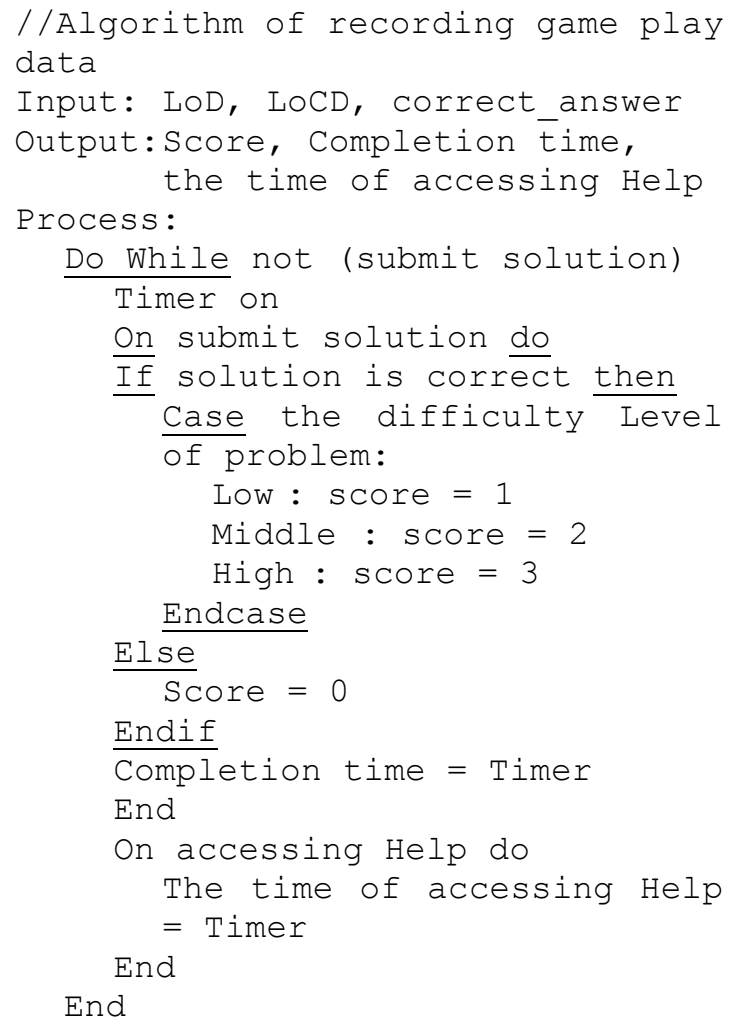




\section{Student Agent}

BoTySeGa defines login access to guarantee uniqueness of data existence for each player. The condition is set in order to make sure that a player relates to the only one learning characteristic. It implies that the only data of player that was not saved beforehand is allowed to pass login access. Player typing username and password to make login access into BoTySeGa is described in the algorithm.

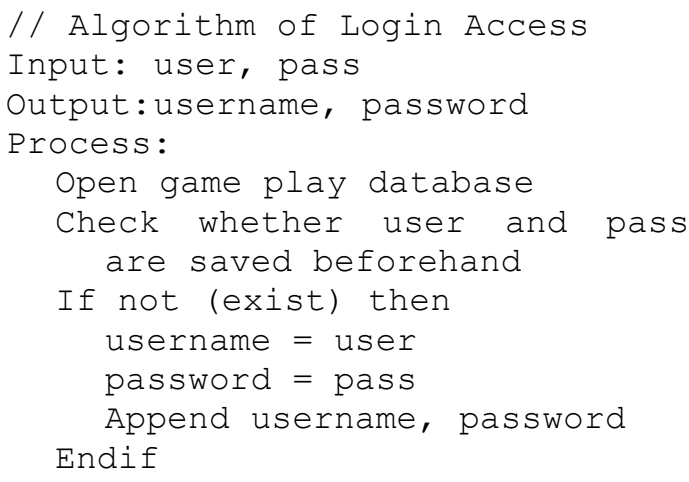

Access to the Help is designed to facilitate players to construct knowledge by themselves. Access is done when a player loses the information required in problem solving. Procedure of access to the Help is conducted as in the following algorithm

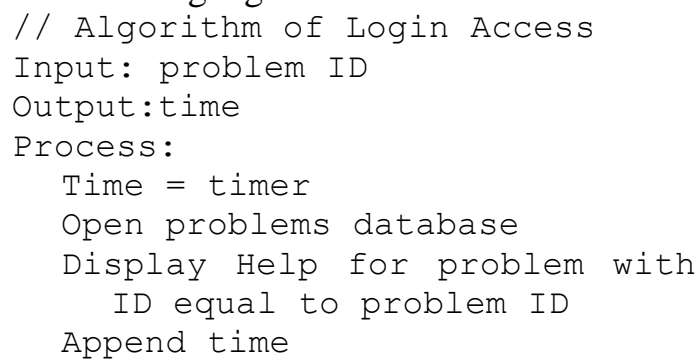

In addition to time in accessing the Help; BoTySeGa also records the players' experience in the form of score and completion time. The value of these attributes triggered through the process of clicking an answer among the four available answers. The algorithm below is the procedure of submit a solution which is designed in BoTySeGa.

// Algorithm of Submit a
solution

Input:

Output:answer

Process:

Return player's answer

\section{Mapping Of Knowledge Distribution in BoTySeGa}

Knowledge that is involved in serious game is a parallelogram. It is a subject matter of $5^{\text {th }}$ grade elementary school learners. Problems are grouped based on two dimensions, i.e.: cognitive domain and level of difficulty. The only the first three of the six cognitive domains of Bloom's taxonomy are adopted in BoTySeGa. Those three domains represent the level of game challenge. Players are faced with three problems in each level of game. The problem could be of low, middle, or high level of difficulty. The grouping of BoTySeGa's problems in two dimensional matrix is shown in Table 3.

Indicators which are implemented in grouping of BoTySeGa's problems are defined in Table 4. Those indicators are arranged on consideration with Bloom's cognitive domain, competency standard of subject matter, and problem's level of difficulty.

\section{BoTySeGa's Challenges Database}

Forty five multiple choice problems are arranged for the BoTySeGa. Those problems are of nine elements of two dimensional matrix of problems distribution. The problems are arranged from six definitions of competencies standard of parallelogram (Table 5).

Table 3. Two Dimensional Matrix of Problems Distribution

\begin{tabular}{cccc}
\hline \multirow{2}{*}{$\begin{array}{c}\text { Level of problem } \\
\text { difficulty }\end{array}$} & \multicolumn{4}{c}{ Cognitive } \\
\cline { 2 - 4 } & $\mathrm{C} 1$ & $\mathrm{C} 2$ & $\mathrm{C} 3$ \\
\hline Low & $\mathrm{C}_{1 \mathrm{~L}}$ & $\mathrm{C}_{2 \mathrm{~L}}$ & $\mathrm{C}_{3 \mathrm{~L}}$ \\
Middle & $\mathrm{C}_{1 \mathrm{M}}$ & $\mathrm{C}_{2 \mathrm{M}}$ & $\mathrm{C}_{3 \mathrm{M}}$ \\
High & $\mathrm{C}_{1 \mathrm{H}}$ & $\mathrm{C}_{2 \mathrm{H}}$ & $\mathrm{C}_{3 \mathrm{H}}$ \\
\hline
\end{tabular}


Table 4. Indicator definition referred in problems classification

\begin{tabular}{|c|c|c|}
\hline No & Group & Indicators \\
\hline 1 & $\mathrm{C}_{1 \mathrm{~L}}$ & $\begin{array}{l}\text { The ability to remember the basic principles "a quadrilateral is a parallelogram" of } \\
\text { specific facts. }\end{array}$ \\
\hline 2 & $\mathrm{C}_{1 \mathrm{M}}$ & $\begin{array}{l}\text { The ability to remember the basic principles "a quadrilateral is a parallelogram" of a } \\
\text { wider range than the only specific facts and classify whether a quadrilateral is a } \\
\text { parallelogram. }\end{array}$ \\
\hline 3 & $\mathrm{C}_{1 \mathrm{H}}$ & $\begin{array}{l}\text { The ability to remember the basic priciples "a quadrilateral is a parallelogram" of } \\
\text { complete theories and classify whether a quadrilateral is a parallelogram. }\end{array}$ \\
\hline 4 & $\mathrm{C}_{2 \mathrm{~L}}$ & $\begin{array}{l}\text { The ability to grasp the basic principles "a quadrilateral is a parallelogram" and } \\
\text { classify whether a quadrilateral stating in another form is a parallelogram. }\end{array}$ \\
\hline 5 & $\mathrm{C}_{2 \mathrm{M}}$ & $\begin{array}{l}\text { The ability to grasp the basic principles "a quadrilateral is a parallelogram", classify } \\
\text { whether a quadrilateral is a parallelogram by interpretating, and calculating value of } \\
\text { an element. }\end{array}$ \\
\hline 6 & $\mathrm{C}_{2 \mathrm{H}}$ & $\begin{array}{l}\text { The ability to grasp the basic principles "a quadrilateral is a parallelogram", classify } \\
\text { whether a quadrilateral is a parallelogram by determining consequences or effects of } \\
\text { previous facts, and calculating value of an element. }\end{array}$ \\
\hline 7 & $\mathrm{C}_{3 \mathrm{~L}}$ & The ability to apply principles of parallelogram in real problem applying basic rules. \\
\hline 8 & $\mathrm{C}_{3 \mathrm{M}}$ & $\begin{array}{l}\text { The ability to apply principles of parallelogram in real problem applying } \\
\text { consequences or effects of previous facts. }\end{array}$ \\
\hline 9 & $\mathrm{C}_{3 \mathrm{H}}$ & $\begin{array}{l}\text { The ability to apply principles of parallelogram in real problem applying } \\
\text { consequences or effects of previous facts integrated with related concepts. }\end{array}$ \\
\hline
\end{tabular}

\section{RESULT AND DISCUSSION}

We have developed a serious game with dynamic difficulty and Bloom's taxonomybased level of challenge. We named the game with BoTySeGa. We conducted UAT against BoTySeGa following the scenario described in Table 6. At the end we also took players' response utilizing Likert-type questionnaire

\section{Login Access}

Game play data are recorded directly by applying database application along with players play BoTySeGa. In order to make easier in identifying data of each player; system also records username and password in addition to data: score, completion time, and the time of

accessing Help. Every time of game play; the data is automatically recorded into the players' database. Username and password are set unique. The only username and password which are not yet recorded only new data. Figure 7 (a-b) depict login access in case of players are permitted to play the game.

Table 5. The Distribution of BoTySeGa's Challenges Database

\begin{tabular}{|c|c|c|c|c|c|c|c|c|c|}
\hline \multirow[t]{2}{*}{ Competency Standards } & \multicolumn{3}{|c|}{$\begin{array}{c}\text { C1 } \\
\text { (Understanding) }\end{array}$} & \multicolumn{3}{|c|}{$\begin{array}{c}\text { C2 } \\
\text { (Comprehension) }\end{array}$} & \multicolumn{3}{|c|}{$\begin{array}{c}\mathbf{C 3} \\
\text { (Application) }\end{array}$} \\
\hline & $\mathbf{L}$ & M & $\mathbf{H}$ & $\mathbf{L}$ & M & $\mathbf{H}$ & $\mathbf{L}$ & M & $\mathbf{H}$ \\
\hline Both pairs of opposite sides are parallel & 1 & 17 & & & & & & & \\
\hline Both pairs of opposite sides are congruent & 3 & 25 & 27 & $14 ; 19$ & 7 & 8 & $35 ; 41$ & & 40 \\
\hline Both pairs of opposite angles are congruent & 2 & 15 & 11 & $23 ; 24$ & $16 ; 18$ & 22 & 30 & 32 & 42 \\
\hline Consecutive angles are supplementary & 6 & 24 & 31 & & 9 & 13 & 37 & 39 & 43 \\
\hline $\begin{array}{l}\text { One pair of opposite sides is congruent and } \\
\text { parallel }\end{array}$ & & 5 & 20 & & 29 & 33 & & 38 & 44 \\
\hline Diagonal bisects each other & 4 & & 10 & 12 & & 36 & 21 & $26 ; 28$ & 45 \\
\hline Number of items & 5 & 5 & 5 & 5 & 5 & 5 & 5 & 5 & 5 \\
\hline
\end{tabular}


Table 6. UAT Scenarios of BoTySeGa

\begin{tabular}{|c|c|c|c|}
\hline No & Scenario & Input & $\begin{array}{c}\text { Expected } \\
\text { output }\end{array}$ \\
\hline 1 & $\begin{array}{l}\text { Leave name or } \\
\text { absence } \\
\text { number empty }\end{array}$ & $\begin{array}{l}\text { Name or } \\
\text { absence } \\
\text { number is } \\
\text { empty }\end{array}$ & $\begin{array}{l}\text { Released the hint } \\
\text { for asking player } \\
\text { to input name or } \\
\text { absence number } \\
\text { before taking } \\
\text { permission for } \\
\text { playing game. }\end{array}$ \\
\hline 2 & $\begin{array}{l}\text { Input name or } \\
\text { presence } \\
\text { number that is } \\
\text { already exists } \\
\text { in database. }\end{array}$ & $\begin{array}{l}\text { Name or } \\
\text { presence } \\
\text { number that } \\
\text { has been } \\
\text { already exist } \\
\text { in database }\end{array}$ & $\begin{array}{l}\text { Released the hint } \\
\text { to let player } \\
\text { know that the } \\
\text { name or presence } \\
\text { number is } \\
\text { already exist in } \\
\text { gameplay } \\
\text { database. }\end{array}$ \\
\hline 3 & $\begin{array}{l}\text { Input name } \\
\text { and presence } \\
\text { number that } \\
\text { have not } \\
\text { existed in } \\
\text { game-play } \\
\text { database. }\end{array}$ & $\begin{array}{l}\text { Name and } \\
\text { presence } \\
\text { number that } \\
\text { have not } \\
\text { existed in } \\
\text { gameplay } \\
\text { database. }\end{array}$ & $\begin{array}{l}\text { Player's name } \\
\text { and presence } \\
\text { number is saved } \\
\text { in gameplay } \\
\text { database. }\end{array}$ \\
\hline 4 & $\begin{array}{l}\text { Bring playing } \\
\text { character to } \\
\text { non-playing } \\
\text { character with } \\
\text { navigation }\end{array}$ & $\begin{array}{l}\text { Bring playing } \\
\text { character to } \\
\text { non-playing } \\
\text { character } \\
\text { without } \\
\text { navigation }\end{array}$ & $\begin{array}{l}\text { No response } \\
\text { released by game } \\
\text { system }\end{array}$ \\
\hline 5 & $\begin{array}{l}\text { Bring playing } \\
\text { character to } \\
\text { non-playing } \\
\text { character } \\
\text { without } \\
\text { navigation }\end{array}$ & $\begin{array}{l}\text { Bring playing } \\
\text { character to } \\
\text { non-playing } \\
\text { character with } \\
\text { navigation }\end{array}$ & $\begin{array}{l}\text { Game system } \\
\text { releases pop-up } \\
\text { communication } \\
\text { to encompass } \\
\text { playing character } \\
\text { movement }\end{array}$ \\
\hline 6 & $\begin{array}{l}\text { Send a wrong } \\
\text { solution for the } \\
\text { third problem } \\
\text { of a cognitive } \\
\text { domain }\end{array}$ & $\begin{array}{l}\text { A wrong } \\
\text { solution for } \\
\text { the third } \\
\text { problem of a } \\
\text { cognitive } \\
\text { domain }\end{array}$ & $\begin{array}{l}\text { Game system } \\
\text { releases "Game } \\
\text { over" state and } \\
\text { stop playing up } \\
\text { to current level }\end{array}$ \\
\hline 7 & $\begin{array}{l}\text { Send a right } \\
\text { solution for the } \\
\text { third problem } \\
\text { of a cognitive } \\
\text { domain }\end{array}$ & $\begin{array}{l}\text { A right } \\
\text { solution for } \\
\text { the third } \\
\text { problem of a } \\
\text { cognitive } \\
\text { domain }\end{array}$ & $\begin{array}{l}\text { Game system } \\
\text { continuous } \\
\text { playing to the } \\
\text { next cognitive } \\
\text { domain except } \\
\text { for the highest } \\
\text { domain } \\
\text { (application). }\end{array}$ \\
\hline 8 & $\begin{array}{l}\text { Send a right } \\
\text { solution for the } \\
\text { third problem } \\
\text { of the third } \\
\text { cognitive } \\
\text { domain }\end{array}$ & $\begin{array}{l}\text { A right } \\
\text { solution for } \\
\text { the third } \\
\text { problem of the } \\
\text { third cognitive } \\
\text { domain }\end{array}$ & $\begin{array}{l}\text { Game system } \\
\text { releases a winner } \\
\text { state and stops } \\
\text { the game. }\end{array}$ \\
\hline
\end{tabular}

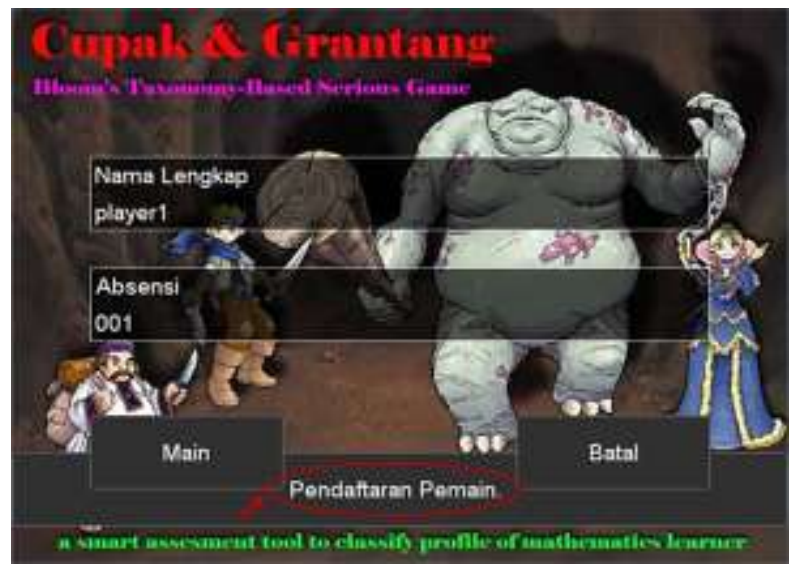

(a)

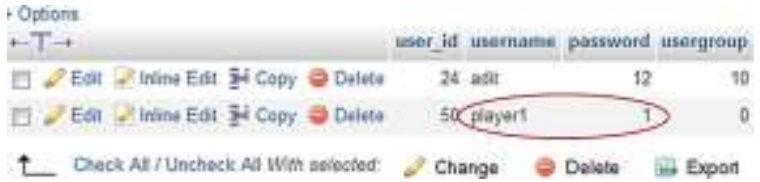

(b)

Figure 7. Pass login Access

On the contrary; Figure 8 (a-b) depict players are not permitted due to the recorded player's data in player's database.

\section{Non-playing character with vs. without Navigation}

There are a number of non-playing characters created in BoTySeGa. Some of them are completed with knowledge to navigate players. Playing character must communicate to non-playing characters equipped with knowledge to navigate the player.

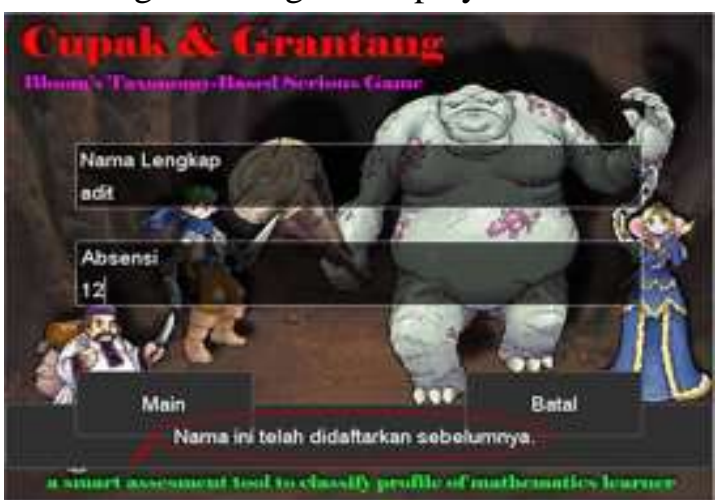

(a)

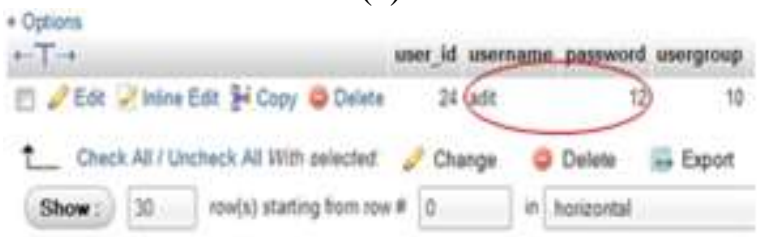

(b)

Figure 8. Fail Login Access 
This approach is designed to encompass players' movement in their adventure. BoTySega implements this scenario involving pop-up menu in which information about "where to go or what to do next" is displayed.

Screenshot in case of player meets non-playing character with navigation knowledge is shown at Figure 9 (a), otherwise at Figure 9 (b).

\section{Continue to the next or Stop up to current level}

Based on Bloom; learning hierarchy starting from simple to complex knowledge/skill. The hierarchy implies that mastery in previous cognitive domain is entirely important to be master in a cognitive domain.

BoTySeGa applies Bloom's hierarchy into a rule which is in charged with filtering of player whom is continued to the next level of cognitive domain or stop up at the current level with "Game Over" state. Filtration mechanism refers to principles contained in Table 2.

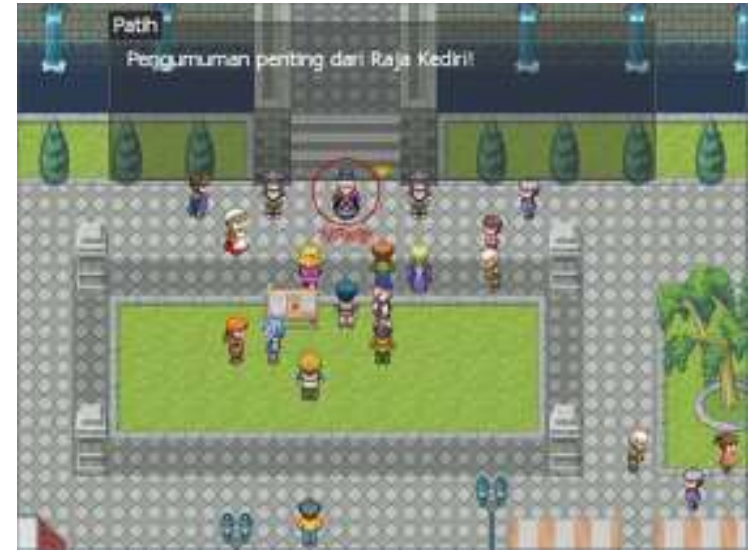

(a)

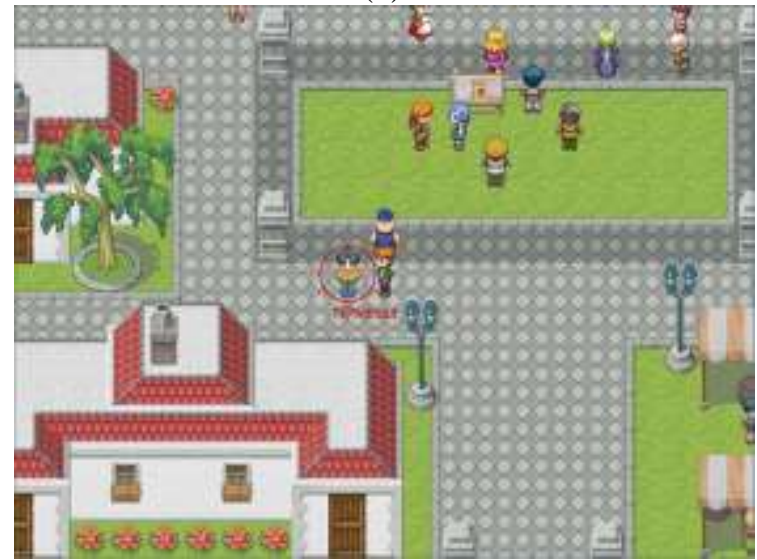

(b)

Figure 9. Two Classes of non-Playing Character

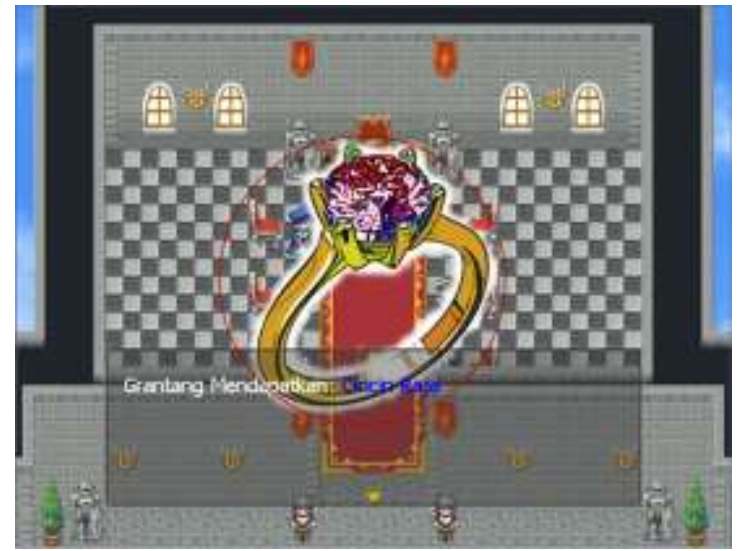

(a)

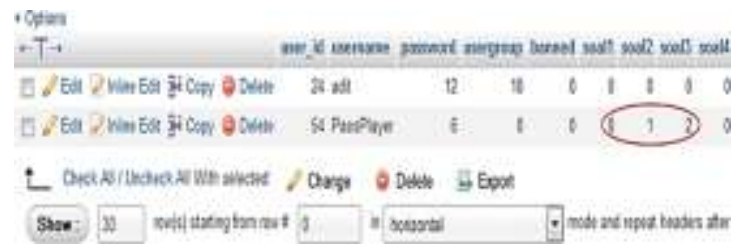

(b)

Figure 10. A case of Continue to the next level

Screenshots in case of a player is permitted to continue to the next level and the game play data are shown at Figure 10 (a-b). In case of a player should stop up at current level; the screenshot and data are shown at Figure 11 (a-b).

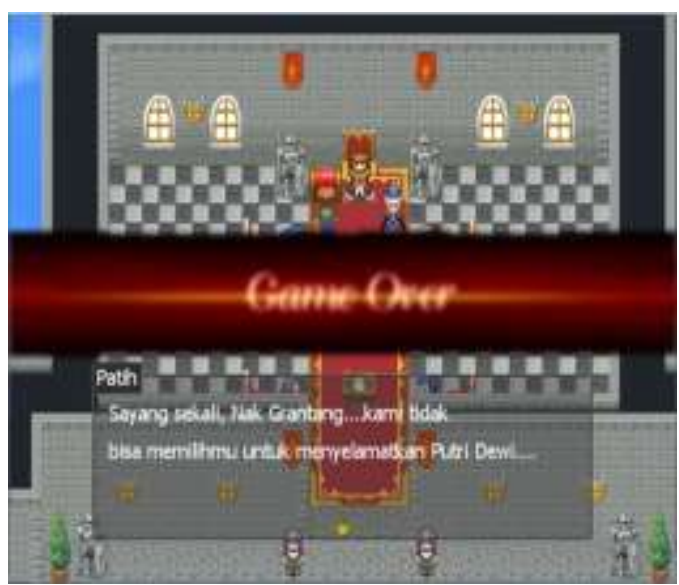

(a)

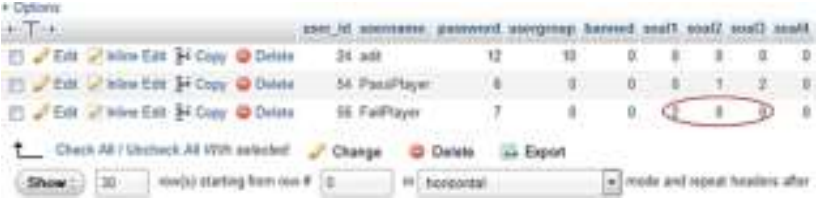

(b)

Figure 11. A case of stop up to current level 


\section{Winner State}

BoTySeGa defines two states of the end of game i.e.: player wins or loses the game. The players who win the game completely solve nine challenges and send a right solution on the last chance.

A Screenshot in case of a player win the game is shown at Figure 12. The data in case of a player in a win state is shown at Figure 13.

\section{Players' Response to BoTySeGa}

$l i$ and $h i$ scores for 15 questions of five point successively are 15 and 75 . Hence the five intervals response categories are:

$$
\begin{aligned}
60 & \leq \mu \\
50 \leq \mu & <60 \\
40 \leq \mu & <50 \\
30 \leq \mu & <40 \\
\mu & <30
\end{aligned}
$$

Highly positive
Positive
Average
Negative
Highly negative

Based on the data of 85 respondents; it is obtained that the mean value of response score is 59.93. The mean value falls within positive category. This value is close to lower value of highly positive category i.e. 60 .

\section{CONCLUSION}

This paper has described the development of Bloom's taxonomy-based serious game which is named BoTySeGa. The game was designed with dynamic level of difficulty and gives consideration to learning hierarchy of Bloom's taxonomy in challenges leveling.

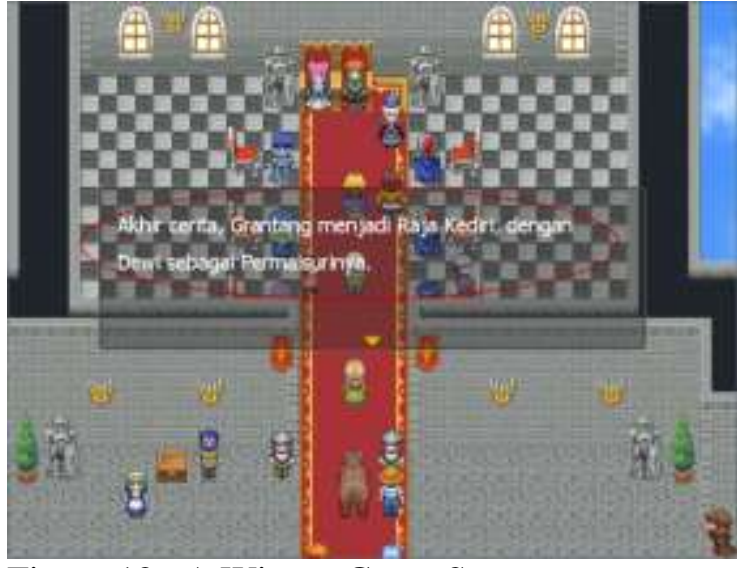

Figure 12. A Winner Game State

Among eight scenarios proposed to test against BoTySeGa, it is found that there is a match between expectation and output results. We found it at all eight scenarios. It informs that the game has fulfilled the requirement specified in game scenario. We also prove that players response positively to the usage of serious game as an assessment for learning. It is shown by average score of players response i.e. 59.93, which is involved is "Positive" interval of category. Hence the implementation of Bloom's taxonomy-based serious game should be taken for consideration as a tool in learning especially in assessment.

\section{ACKNOWLEDGMENT}

This research was funded through the research

\begin{tabular}{|c|c|c|c|c|c|c|c|c|c|c|c|c|c|c|c|c|c|c|c|c|c|}
\hline 24 ath & 12 & 10 & 0 & 0 & 0 & 0 & 0 & 0 & 0 & 0 & 0 & 0 & 0 & 0 & 0 & 0 & 0 & 0 & 0 & 0 & 0 \\
\hline 54 PassPlyer & 6 & 0 & 0 & 0 & 1 & 2 & 0 & 0 & 0 & 0 & 0 & 0 & 3 & 13 & 35 & 0 & 0 & 0 & 0 & 0 & 0 \\
\hline 56 Falfisyer & 1 & 0 & 0 & 2 & 0 & e & 1 & 1 & 1 & 0 & 1 & 1 & 5 & 15 & 12 & 0 & 0 & 0 & 0 & 0 & 0 \\
\hline G2 winPlyyer & 8 & 0 & 0 & 0 & 1 & 2 & 0 & 2 & 3 & 3 & 3 & 3 & 2 & 13 & 24 & 4 & 8 & 28 & 20 & 8 & \\
\hline
\end{tabular}
scheme of Doctoral Dissertation, directorate of research and community service, the Ministry of research, technology and higher education with contract number: 21/UN48.14/PL/2015.

Figure 13. A Winner Game Play Data 
We greatly thank you for the support so this research is carried out according to research plan. We also thank you to the students of SDN 3 Banjar Jawa and SD Laboratorium Undiksha for the responses that is delivered regarding to BoTySeGa.

\section{REFERENCES}

[1]D. M. A. Sluijsmans and K. Struyven, "Quality assurance in assessment: An introduction to this special issue," Stud. Educ. Eval., vol. 43, pp. 1-4, Dec. 2014.

[2] M. Andrade Aréchiga, G. López, and G. López Morteo, "Assessing effectiveness of learning units under the teaching unit model in an undergraduate mathematics course," Comput. Educ., vol. 59, no. 2, pp. 594-606, Sep. 2012.

[3] S. Chen \& D. Michael, "Proof of learning: Assessment in serious games." Oct-2005. [Online]. Available: http://www.unco.edu/cetl/ sir/stating_outcome/documents/Krathwohl.p df [Accessed: 24-Oct-2015].

[4] N. Brody, "A plea for the teaching of intelligence: Personal reflections," Intelligence, vol. 42, pp. 136-141, Jan. 2014.

[5] J. N. Gardner and J. Gardner, Assessment and Learning. SAGE, 2012.

[6] C. DeLuca, K. Luu, Y. Sun, D. A. Klinger, and others, "Assessment for learning in the classroom: Barriers to implementation and possibilities for teacher professional learning," 2012.

[7] V. Klenowski, "Assessment for learning revisited: An Asia Pacific perspective," 2009.

[8] L. Mabry, J. Poole, L. Redmond, and A. Schultz, "Local impact of state testing in southwest Washington," Educ. Policy Anal. Arch., vol. 11, p. 22, 2003.

[9] G. T. Brown, K. J. Kennedy, P. K. Fok, J. K. S. Chan, and W. M. Yu, "Assessment for

[16] C. Conati and X. Zhao, "Building and evaluating an intelligent pedagogical agent

student improvement: Understanding Hong Kong teachers' conceptions and practices of assessment," Assess. Educ. Princ. Policy Pract., vol. 16, no. 3, pp. 347-363, 2009.

[10] A. Hargreaves, "Five Flaws of Staff Development and the Future Beyond.," $J$. Staff Dev., vol. 28, no. 3, pp. 37-38, 2007.

[11] M. Webb, D. Gibson, and A. Forkosh Baruch, "Challenges for information technology supporting educational assessment," J. Comput. Assist. Learn., vol. 29, no. 5, pp. 451-462, 2013.

[12] N. Suttie, S. Louchart, T. Lim, and J. Ritchie, "Towards a Biocybernetic Approach for Serious Games Real-time Psychophysiological Inferences for Adaptive Agents in Serious Games," Procedia Comput. Sci., vol. 15, pp. 316317, 2012.

[13] F. Bellotti, B. Kapralos, K. Lee, and P. MorenoGer, "User assessment in serious games and technology enhanced learning," Adv. Hum.Comput. Interact., vol. 2013, 2013.

[14] G. Wallner, "Play Graph: A methodology and visualization approach for the analysis of gameplay data.," in FDG, 2013, pp. 253260.

[15] C. S. Loh and Y. Sheng, "Maximum Similarity Index (MSI): A metric to differentiate the performance of novices vs. multiple experts in serious games," Comput. Hum. Behav., vol. 39, pp. 322-330, Oct. 2014. 
to improve the effectiveness of an educational game," in Proceedings of the 9th international conference on Intelligent user interfaces, 2004, pp. 6-13.

[17] M. A. Syufagi, M. Hariadi, and M. H. Purnomo, "A cognitive skill classification based on multi objective optimization using learning vector quantization for serious games," J. ICT Res. Appl., vol. 5, no. 3, pp. 185-202, 2011.

[18] N. Yusof, M. S. Othman, N. B. Ahmad, and Y. C. Nyen, A Concise Fuzzy Rule Base to Reason Student Performance Based on Rough Fuzzy Approach. INTECH Open Access Publisher, 2012.

[19] N. E. Dunbar, C. H. Miller, B. J. Adame, J. Elizondo, S. N. Wilson, B. L. Lane, A. A. Kauffman, E. Bessarabova, M. L. Jensen, S. K. Straub, and others, "Implicit and explicit training in the mitigation of cognitive bias through the use of a serious game," Comput. Hum. Behav., vol. 37, pp. 307-318, 2014.

[20] J. Feldman, A. Monteserin, and A. Amandi, "Detecting students' perception style by using games," Comput. Educ., vol. 71, pp. 14-22, 2014.

[21] M. Minović, M. Milovanović, U. Šošević, and M. Á. C. González, "Visualisation of student learning model in serious games," Comput. Hum. Behav., vol. 47, pp. 98107, 2015.

[22] N. Sukajaya, K. E. Purnama, and M. H. Purnomo, "Intelligent Classification of Learner's Cognitive Domain using Bayes Net, Naïve Bayes, and J48 Utilizing Bloom's Taxonomy-based Serious Game," Int. J. Emerg. Technol. Learn. IJET, vol. 10, no. 2, pp. 46-52, Mar. 2015.

[23] D. Vidakovic, J. Bevis, and M. Alexander, "Bloom's taxonomy in developing assessment items," $A M C$, vol. 10, p. 12, 2003.

[24] K. W. Hawks, "The effects of implementing Bloom's taxonomy and utilizing the Virginia standards of learning curriculum framework to develop mathematics lesson for elementary students.," Liberty University, 2010.

[25] J. T. Fullerton, J. B. Thompson, and P. Johnson, "Competency-based education: The essential basis of preservice education for the professional midwifery workforce," Midwifery, vol. 29, no. 10, pp. 1129-1136, 2013.

[26] M.K. Kim, R. A. Patel, J. A. Uchizono, and L. Beck, "Incorporation of Bloom's Taxonomy into Multiple Choice Examination Questions for a Pharmacotherapeutics Course," Am. J. Pharm. Educ., vol. 76, no. 6, p. 114, 2012.

[27] S. Sampayo Vargas, C. J. Cope, Z. He, and G. J. Byrne, "The effectiveness of adaptive difficulty adjustments on students' motivation and learning in an educational computer game," Comput. Educ., vol. 69, pp. 452-462, 2013.

[28] D. R. Krathwohl, “A Revision of Bloom's Taxonomy: An Overview. (PDF) in Theory into Practice. V 41. \#4. Autumn, 2002. Ohio State University.," The Second Principle, 2002. .

[29] A. R. Reeves, Where great teaching begins: Planning for student thinking and learning. ASCD, 2011.

[30] M. Harfield, Not Dark Yet: A very funny book about a very serious game. Loose Chippings, 2010.

[31] C. C. Abt, Serious games. University Press of America, 1987.

[32] B. Sawyer and D. Rejeski, "Serious games: Improving public policy through game-based learning and simulation," 2002.

[33] B. Bergeron, "Developing serious games (game development series)," 2006.

[34] M. S. El-Nasr, A. Drachen, and A. Canossa, Game analytics: Maximizing the value of player data. Springer Science \& Business Media, 2013. 
[35] J. Cannon Bowers, Serious Game Design and Development: Technologies for Training and Learning: Technologies for Training and Learning. IGI Global, 2010.

[36] D. Djaouti1\&2, J. Alvarez, J.P. Jessel, and O. Rampnoux, "Origins of Serious Games," 2012.

[37] C. Obikwelu and J. C. Read, "The Serious Game Constructivist Framework for Children's Learning," Procedia Comput. Sci., vol. 15, pp. 32-37, 2012.
[38] A. de Ribaupierre, "Piaget's Theory of Cognitive Development," in International Encyclopedia of the Social \& Behavioral Sciences (Second Edition), J. D. Wright, Ed. Oxford: Elsevier, 2015, pp. 120-124.

[39] A. Kozulin, "Vygotsky's Theory of Cognitive Development," in International Encyclopedia of the Social \& Behavioral Sciences (Second Edition), J. D. Wright, Ed. Oxford: Elsevier, 2015, pp. 322-328.

[40] TILE-SIG Feature: The "Digitally Enhanced" Zone of Proximal Development. 